\title{
Markalarda Koronavirüs Etkisi: Sosyal Mesafe Logoları (Coronavirus Effect on Brands: Social Distance Logos)
}

\section{Merve GENÇYÜREK ERDOĞAN iD a Volkan YAVUZ iD $b$}

a Ankara Hacı Bayram Veli Üniversitesi, Polatlı Sosyal Bilimler MYO, Ankara, Türkiye, merve.gencyurek@hbv.edu.tr

b Ankara Hacı Bayram Veli Üniversitesi, Polatlı Sosyal Bilimler MYO, Ankara, Türkiye, v.yavuz@hbv.edu.tr

\begin{tabular}{ll}
\hline MAKALE BİLGISİ & ÖZET \\
\hline Anahtar Kelimeler: & $\begin{array}{l}\text { Amaç - Marka bağlılı̆̆ı ve markanın tercih edilmesinde önemli bir unsur olan logolar, tüketici ile marka } \\
\text { arasında istenilen mesajın iletilmesinde son derece etkilidir. Marka logoları, tüketicinin zihninde yer } \\
\text { Koronavirüs }\end{array}$ \\
$\begin{array}{l}\text { eden, markayı temsil eden, hatırlatan ve marka değerini yansıtan simgelerdir. Çalısmanın amacı; tüm } \\
\text { dünyayı etkisi altına alan Covid-19 salgını sonrası "sosyal mesafe" uygulamaları kapsamında küresel } \\
\text { firmaların marka logolarındaki değişimlerinin incelenmesidir. }\end{array}$
\end{tabular}

Yöntem - Araştırma hem dilsel, hem de dil dışı göstergeleri incelemeye yönelik bir yaklaşım olan göstergebilim yöntemi ile gerçekleştirilmiştir. Göstergebilim; metinlerin içindeki ögelerin hem kendi Gönderilme Tarihi 10 Mayıs özelinde, hem de bütünü kapsayan bir yapıda dış dünya ile ilişkilerini çözümlemede kullanılan bir 2020 araştırma yöntemidir. Çalışma kapsamında markaların güncelledikleri "sosyal mesafe" temalı yeni logoları, göstergebilim yöntemi ile incelenmiştir.

Revizyon Tarihi 30 Haziran 2020

Bulgular - Araştırma sonuçlarına göre öncelikle küresel çaptaki firmaların logo güncellemesi yaparak, Kabul Tarihi 2 Ağustos 2020 "sosyal mesafe"nin önemine dikkat çekmek için çalışmalar başlattıkları tespit edilmiștir. Logolarında temel tasarım ögelerinden "aralık" kullanarak, "sosyal mesafe" temalı yeni logo yayınlayan markalardan; Volkswagen, Audi, Hyundai, McDonals ve CocaCola araştırma kapsamında incelenmiş̧tir. Firmalar yeni logoları ile salgın dönemine ilişkin farkındalıklarını ve "sosyal mesafe" uygulamalarına verdikleri

Makale Kategorisi: Araştırma Makalesi destekleri göstermiş ayrıca, süreci marka stratejilerinin bir parçası olarak yöneterek, tüketicilerin belleklerinde olumlu imaj yaratmıştır.

Tartışma - Çalışma neticesinde "sosyal mesafe" kavramının Covid-19 sonrası literatürde yeni içerikler ile güncellenmesinde fayda olduğu düşünülmektedir. Günümüz şartlarında "sosyal mesafe" bir tercih değil, gerekliliktir. Markaların "sosyal mesafe" temalı yeni logo güncellemelerinin, marka değerlerini arttırmada etkili olabileceği öngörülmektedir.

\begin{tabular}{ll}
\hline ARTICLE INFO & ABSTRACT \\
Keywords: & $\begin{array}{l}\text { Purpose - Logos, which are significant factors for brand loyalty and brand preference, are quite effective } \\
\text { in the course of conveying the message requested between consumers and brands. Brand logos are } \\
\text { Coronavirus }\end{array}$ \\
Social distance & $\begin{array}{l}\text { symbols that are imprinted on the consumers mind, represent and remind the brand, and reflect the } \\
\text { brand value. The purpose of the study is that the changes of brand logos of global companies are analyzed } \\
\text { in the scope of "social distance" applications after Covid-19 pandemic, which exercises influence over } \\
\text { the whole world. } \\
\text { Design/methodology/approach - The study is carried out with the method of semiology that is an } \\
\text { approcah to analyze both linguistic and non-linguistic indicators. Semiology is a research method that is } \\
\text { used to work out the relationships of items within the texts with external world for itself and a structure } \\
\text { forming whole. In the scope of study, new logos with "social distance" -themed, which the brands } \\
\text { Revised 30 June 2020 } \\
\text { update, have been analyzed with the method of semiology. } \\
\text { Findings - According to research results, it has been determined that the global companies began some } \\
\text { studies to take notice of importance of "social distance" by updating their logos. Among the brands, } \\
\text { Research Article }\end{array}$ \\
$\begin{array}{l}\text { which publish the new logo with "social distance" - themed by using "spacing" that is one of the basic } \\
\text { design items in their logos; Volkswagen, Audi, Hyundai, McDonalds and CocaCola have been analyzed } \\
\text { in the scope of the research. The companies showed their awareness with their new logo related to } \\
\text { pandemic period and their supports for "social distance" applications. Also, the brands created the } \\
\text { positive image on the minds of the consumers by managing the process as a part of brand strategies. } \\
\text { Discussion - As a result of the study, it is considered that it is useful to update the notion of "social } \\
\text { distance" with the new contents in the literature after Covid-19. In today's conditions, "social ditance" is } \\
\text { not a choice, but necessity. It is predicted that brands' new logo updates with "social distance" - themed } \\
\text { can be effective for increasing the brand values. }\end{array}$
\end{tabular}




\section{GİRİs}

İlk olarak Çin' de başlayan ve daha sonra bütün dünyayı etkisi altına alan Covid-19 virüsü sonrası, toplumların ekonomik, kültürel ve sosyolojik yapılarında çeşitli değişimler yaşandı. 2019 yılında başlayan ve 2020 yılı itibariyle dünya genelinde hızla yayılan virüs, binlerce insanın hayatını kaybetmesine neden oldu. Ülkeler, yayılımın başlaması ile birlikte çeşitli önlem politikaları ile süreci kontrol altında tutmaya çalıştı. Sosyal mesafenin korunmasına yönelik planlamalar, bu önlemlerin ilk sıralarında yer aldı. Tarihte yaşanan salgınlarda (1918 İspanyol gribi, 2014 Ebola epidemisi gibi) yapılan uygulamalar ve çalışmalar, bireylerin sosyal temaslarını azalttıklarında bu durumun virüsün yayılım hızına olumlu katkı sağladığını ortaya koymuştur. Dolayısıyla sosyal temasın azalmasının, bireylerin sosyal mesafelerini korumaları ile doğrudan ilişkili olduğu düşünülmektedir. Sosyal mesafe kavramı yaşanan bu süreçte, bireylerin aralarına mesafe koymaları, yakın temastan kaçınmaları, risk grubunda olanlar ve virüs taşıyıcılarının kendilerini izole etmeleri anlamlarına gelmektedir. Bu kapsamda dünya çapında hastalıkla mücadele eden bütün ülkelerde "sosyal mesafe" konusunda çok sayıda önlem alınmıştır. Özellikle toplu bulunulan mekanlardan (toplu taşıma araçları, alışveriş merkezleri, çalışma alanları vb.) uzak durmak, teması en aza indirmek, üç metre mesafe kuralını uygulamak alınan sosyal mesafe önlemlerinden bazıları olarak sıralanabilir.

Literatürde sosyal mesafe kavramı daha çok bireylerin yaşadıkları toplumdan, kendilerini ait hissettikleri gruptan, farklı olanlara karşı "tercihen” uyguladıkları bir eylem olarak tanımlanmıştır. Oysa Covid-19 salgını sonrası sıklıkla gündeme gelen sosyal mesafe kavramı, bir tercihten öte gereklilik ve hatta zorunluluk olarak mesafe koymayı tanımlayan yeni bir anlamlandırmayı işaret etmektedir.

\section{KAVRAMSAL ÇERÇEVE}

\subsection{Sosyal Mesafe}

Emory Bogardus (1959:7-11) "sosyal mesafe" (social distance) kavramını, bir sosyal sinıfa ait bireyler ve gruplar arasındaki ilişkilerin (o sınıfa mensup bireyler arasında hiyerarşik ilişki, nüfusun içindeki sınıfların birbiri ile ilişkisi ve belirli bireylerin aralarındaki sosyal farklılık ilişkileri gibi) sempatik anlayışın derecesi olarak tanımlamıştır. Marshall (1999:750) sosyolojik olarak sosyal mesafe kavramını, sosyal grupların mahremiyet sınırlarını işaret eden, toplumsal değişkenlere dayalı olarak oluşturulan yakınlık ya da uzaklık olarak ifade etmiştir. Sosyal mesafe, sosyal psikolojide bir toplumda yaşayan bireylerin din, milliyet, 1rk, etnik köken gibi farklı sosyal gruplara mensup üyelerinin birbirlerini kabul etme ve reddetme derecesi olarak tanımlanabilir (Budak, 2000:690). Sosyal mesafe kavramının ardındaki ana fikir; herhangi bir sosyal ilişkinin "yakınlık" ve "uzaklık" ilişkilerini içermesidir. Bununla birlikte, mesafenin sosyolojik bir kavram olarak kavramsallaştırılmasının çeşitli yolları mevcuttur. Bunlar; duygusal, normatif, interaktif (etkileşimli) ve sosyokültürel olarak sıralanabilir. Bir grubun diğerleri hakkında ne hissettiği, "biz" ifadesinin "onlardan" nasıl ayrıştığı, bireylerin birbirleri ile hangi sıklıkta etkileşimde bulunduğu ve grupların benzer özellikleri ne ölçüde paylaştığı gibi. Tüm bu farklı boyutların birbirleri ile ve diğer mesafe türleri ile nasıl etkileşime girdiği önemlidir. Bir toplumda "yabancılar" ile etkileşim arttıkça, "bizi" "onlardan" ayıran normların modern toplumlarda giderek daha sorunlu hale geldiği ve hem hoşgörülü hem de düşmanca tutumlara yol açtığ1 bilinmektedir (Karakayalı, 2015). Bu bağlamda değerlendirildiğinde sosyal mesafe, bir toplumda yaşayan bireylerin, kendilerinden olmayan ya da farklı bir kimliğe, mezhebe, millete mensup olan, azınlık olarak görülen ya da göçmen gruplara karşı anlayış, hoşgörü derecesi olarak tanımlanmaktadır. Özellikle göç ve göçmenler ile ilgili çalışmalarda, sosyal mesafe kavramının sıklıkla kullanıldı̆̆ı literatürde yer alan kaynaklarda görülmektedir.

Yiğitoğlu ve Vural (2019) sosyal mesafe kavramını toplumun sığınmacı bireylere yönelik duygu ve düşünceleri çerçevesinde ele almış, ayrıca bireylerin sosyo-demografik özelliklerinin sosyal mesafeye etkisi olduğunu belirtmiştir. Eser ve Uygur (2019) tarafından yapılan bir çalışmada Türkiye Cumhuriyeti vatandaşlarının, Suriyeli göçmenlere yönelik sosyal mesafe düzeyleri incelenmiştir. Yüz yüze anket yöntemi ile yürütülen araştırmada katılımcıların etnik kimliklerine göre Suriyeli göçmenlere yönelik algıladıkları sosyal mesafe arasında anlamlı bir farklılık olduğu belirtilmiştir. Bilgiç vd. (2014) tarafından yapılan bir alan çalışmasında ise Türkiye'de karşıt gruplarda yer aldığı düşünülen etnik gruplar, mezhepler ve siyasi parti seçmenleri üzerinden sosyal mesafe kavramı ele alınarak, sosyal mesafe ölçümü yapılmıştır. Çalışma sonucunda siyasi parti seçmenleri arasındaki sosyal mesafenin en yüksek boyutta olduğu belirtilmiştir. Karslı (2013) yaptı̆̆ çalışmada bireylerin başkalarını değerlendirme kriteri olarak bireysel ve grupsal süreçlerin 


\section{Gençyürek Erdoğan - V. Yavuz 12/3 (2020) 2501-2514}

analizini yapmış, sosyal mesafe özelinde Alevilere ve Sünnilere yönelik tutumları ele almıştır. Araştırma sonucuna göre sosyal mesafenin uzaklık veya yakınlık derecesinin sınırlarını çizen etkenler; yaşam tarzını koruma, geleneği yaşatma, kalıp yargılar, dinsel algılama gibi tutumlardır. Üstel ve Caymaz (2009) tarafından yapılan "Seçkinler ve Sosyal Mesafe" başlıklı araştırmada ise orta üst gelir grubundan, eğitim seviyesi yüksek, iyi meslek pozisyonuna sahip seçkinlerin, Lozan azınlıkları, Kürtler ve İslami kesime yönelik sosyal mesafe pratikleri değerlendirilmiştir. Ulusal literatürde "sosyal mesafe" özelinde yapılan araştırmalar incelendiğinde günümüz şartlarında kavramın sağlık özelinde "farklılaşan" bir anlamlandırmasının olduğu ve bu durumun kavramın kullanım alanının küresel çapta değişimini ortaya çıkarmaktadır.

\subsection{Să̆lık İçin Sosyal Mesafe}

Sosyal mesafe kavramının bir istek ya da tercih olmaktan öte gereklilik ve hatta zorunluluk olduğu süreç, Covid-19 virüsünün salgın hastalık olarak yaygınlaşmasından sonra başlamışıı. Virüsün yayılmasındaki ana unsurun "temas" olduğunu belirten araştırmaların giderek çoğalması, sosyal mesafe kavramının fiziksel temasın en aza indirgenecek şekilde anlamlandırılmasını sağlamıştır. Günümüzde sosyal mesafe, geniş bir topluluktaki insanlar arasındaki etkileşimi ve teması azaltmak için kullanılan bir kavramdır. Özellikle solunum yolu ile bulaşabilen hastalıklar, bireylerin yakın temaslarında çok hızlı yayılacağından sosyal mesafe bulaşıcılığı önleyecek önemli bir etkendir. Sosyal mesafe, sadece virüsü taşıyan ya da maruz kaldığı tespit edilen bireyler için değil, topluca hareket edilen tüm alanlarda önemli ve gereklidir. Okulların, çalışma ofislerinin kapatılması, etkinliklerin ve toplantıların iptal edilmesi sosyal mesafe önlemleri arasında yer almaktadır (Wilder-Smith ve Freedman, 2020:2). Covid-19 virüsünün bulaşma zincirini durdurarak, hastalığ1 yavaşlatma amacı taşıyan sosyal mesafe önlemleri, temelde bireyler arasında an az bir metrelik mesafeyi korumayı öngörmektedir. Sosyal mesafe, bireyler arası sanal sosyal bağlantıyı teşvik ederken, zorunlu olmayan tesis ve hizmetlerin kapatılması, savunmasız grupların korunması, evde kalma önlemleri, ulusal düzeyde hareket kısıtlamaları ile düzenlenmiştir (WHO, 2020). Ampirik çalışmalar sosyal ilişkilerin uzun mesafeli seyahatlerden etkilendiğini göstermektedir. Bu nedenle göç akışları takip edilmesi gereken verileri içermektedir. Örneğin A şehrinde doğmuş ve büyümüş bir kişi B şehrinde çalışıyorsa, orada yaşanan salgını A şehrindeki ailesine ve arkadaşlarına aktarması muhtemeldir. Dolayısıyla yayılımdaki en önemli unsurlardan biri sosyal mesafenin korunmasıdır (Chen vd., . 2020: 3).

Kavramı sağlık açısından değerlendirdiğimizde, ülkelerin sıraladıkları önlem listelerinde sosyal mesafenin üst sıralarda olduğunu ve kavramın anlamlandırılmasının sadece fiziksel mesafeyi korumaktan öte bireysel izolasyona kadar uzanan bir yapıda olduğu görülmektedir. Dolayısıyla ulusal ve uluslararası çapta bütün şirketler, hem müşterileri hem de çalışanları için çeşitli sosyal mesafe önlemleri alarak, bu önlemleri de dijital platformlar aracılığı ile paylaşmışlardır. Sosyal hayatın sürekliliğinin bir parçası olan tüm kurumlar (eğitim kurumları, kütüphaneler, spor ve müzik etkinlikleri vb.) dijital kanallar aracıllı̆g ile hedef kitlesine ulaşmaya devam etmektedir. Yerel yönetimler, kamu kurumları ile özel sektör kuruluşları Covid-19 kapsamında çok sayıda sosyal mesafe önlemi yayınlamıştır. Bunlara ek olarak dünya çapında çok sayıda şirket, sosyal mesafenin önemine dikkat çekmek için çeşitli stratejiler uygulamıştır.

Araştırmanın konusu; markaların Covid-19 döneminde geliştirdikleri stratejiler kapsamında sosyal mesafenin önemine dikkat çeken logo tasarımlarıdır. Markanın tüketici nezdinde ve sektörde konumlanmasında önemli rolü olan logolar, firmalar tarafından sosyal mesafe temalı yeniden güncellenerek, reklam mecralarında yerini almıştır. Görsel tasarımın önemli sembollerinden olan logolar, tüketicilerin markaya karşı tutumlarında ve markaya olan bağlılık olgularında önemli unsurlar arasındadır.

\subsection{Görsel İletişimde Logo}

Tarihte ticaretin ve ana malın yaşama olan dolaylı ve/veya dolaysız etkisi ile kurumların da kendilerini ötekilerden ayrı kılmak adına simgeleşmeye giderek, bir kimlik oluşturma çabası içine girdikleri gözlenmektedir. 17.yüzyılda çömlekçilerin ürettikleri işlerin altına koydukları işaretlerde, toplumsal boyuttaki statü farklılı̆̆ının ve aidiyetin ilk göstergelerine ise soyluların, kralların kullandıkları armalardaki simgelerde rastlanmaktadır (Ak, 1998: 27). Sanayi devriminden sonra üretim olanaklarının gelişmesi ve serbest ekonomi piyasasında kıyasıya bir yarışın başlaması, üreticilerin bu rekabet ortamında daha iyi konumlanabilmesini gerektirmiştir. Bunun için kullanılan enstrümanlardan birisi de; kurumsal kimlik çalışmaları olmuştur. Kurumsal kimliğin de şüphesiz ilk unsuru amblem, yani logo'dur. Becer (1997:194)'e göre amblem "ürün ya da hizmet üreten kuruluşlara kimlik kazandıran, sözcük özelliği göstermeyen, soyut 
ya da nesnel görüntülerle ya da harflerle oluşturulan simgedir". Bayraktaroğlu ve Çalış (2010: 9), kurum kimliğinin görsel tasarım unsurlarından olan amblem ve logo'ya indirgenmiş olduğunu ve iletişim tasarımı bağlamında kullanılan etkili birer görsel kimlik unsuru olduğunu ifade etmektedir. Şüphesiz logosuz bir kurumsal kimlik düşünülememektedir ve logoların içinde bulunulan durumda bazı zamanlarda güncellenmesi de gerekmektedir. Birçok firmanın tarihte logolarını güncelledikleri bilinmektedir.

\subsection{Markalar İçin Logo Tasarımı}

Logo tasarımları, yakın süreçte tasarım alanında en çok üzerinde durulan konulardan birisi olmuştur. Uygun logo tasarımlarının markaları başarıya götürdüğü görüldüğü için logo tasarımları konusunda çalışmalar artmıştır. Ries'e (2004:125) göre logo; "markanın görsel simgesi olan bir amblem ile markanın/kuruluşun isminin ayırt edici biçimde bir araya gelmesiyle oluşur". Şüphesiz işletmenin tüketiciler tarafından devamlı olarak tercih edilmesini sağlayabilecek en önemli araç da "marka" olmaktadır (Akalan ve diğ, 2019: 788). Rekabetin gün geçtikçe artması ve ürünler arasındaki farklılıkların ortadan kalkmaya başlaması yeni pazarlama stratejileri geliştirmeyi kaçınılmaz hale getirmiştir (Tarakçı Erdoğan, 2019: 574).

Logoların tasarımında, insanların ilgisini çekme, güven oluşturma, satın alma eyleminin altyapısını hazırlama, mesaj verme, bağımlılık yaratma, estetik duyguları besleme, eğlendirme ve sosyal mesaj verme gibi durumlar dikkate alınmaktadır. Uygun logo tasarımı, markanın geçmişine vurgu yapabilirken, aynı zamanda markanın sektördeki konumlanmasına da yardımcı olmaktadır. Logolar hazırlanırken temel tasarım ilkelerine bağlı olarak bir süreç yürütülmesi gerekmektedir. Ayrıca hazırlama aşamasında bu logoların her türlü ortama uyum sağlayabilecek sadelikte olması da önem taşımaktadır.

Logolar tasarlanırken tipografik karakterler veya semboller kullanılmaktadır. Marka iletişiminde insanların zihinlerinde canlandırabilmeleri açısından sembolik logo tasarımları ön plana çıkarken bazı tasarımlarda markaların sadece tipografik unsurlar kullandığı da görülmektedir. Hem sembolik, hem de tipografik unsurların olduğu logolar da yaygın olarak kullanılmaktadır. Bu durumda logo tasarımları, sembolik ve tipografik olarak iki farklı şekilde incelenebilir (Bozkurt, 2015: 18).

Tarihsel süreçte yazı, bir iletişim unsuru olarak kullanılmasının yanında dekoratif bir öğe olarak da kullanılmıştır. Birçok medeniyetin, günümüze kadar ulaşan eserlerinde tipografik unsurları kullandığ1 görülmektedir. Rönesans döneminin tipografik karakterleri hemen herkes tarafından bilinmektedir. Aynı zamanda İslam toplumunda da halen Arapça tipografik karakterler kutsal alanların süslemesinde kullanılmaktadır.

Tipografik unsurlardan oluşan logolar, Parlak (2011: 128)'a göre beş farklı şekilde yapılmaktadır. Bunlardan ilki; sans serif stili logolardır. Tırnaksız bir yazı tipi kullanılarak yapılan bu logolar, tasarım açısında köşeli ve kesin oldukları için güçlü bir görünüme sahiptir. İkincisi; tek karakterden oluşan logolardır. Birçok kaynakta logoların en az iki karaktere sahip olması görüşü hakimken dünyaca ünlü bazı markalar sadece tek bir karakterden oluşan logolar kullanmaktadır. Üçüncü logo tipi de; çok karakterden oluşan logolardır. Bu logolarda en az iki tipografik karakter bulunmaktadır. Dördüncü tür; tipografik logolar kombinasyon tipi logolar olarak bilinir, iki ya da daha fazla karakterden oluşurlar ve bazılarında deforme edilmiş tipografik öğeler göze görülür. Tipografik unsurlardan oluşan logoların son türü ise; geleneksel olmayan logolardır. Birçok global firma (IBM, Samsung Coca-Cola vb.) bu türde logo kullanmaktadır.

Sembollerin kullanıldığı logolar da oldukça yaygın şekilde kullanılmaktadır. İnsanlar tarih boyunca iletişim kurmak amacıyla işaret ve semboller üretmişlerdir. Sembollere insanlar zamanla farklı anlamlar da yüklemişlerdir. Bazı semboller yine bu süreçte evrensel anlamlar da taşımaya başlamıştır. Farklı kültürlerden gelen ve farklı dilleri konuşan insanlar, bu sembollerin taşıdığı anlamı aynı şekilde idrak edebilir duruma gelmiştir. Bu evrensellik, logo tasarımlarında da markalar için oldukça avantajlı bir durum ortaya koymaktadır. Sanatsal bir çıktı olarak dikkate alındığında semboller ve iletişim bağdaştıııldığında, düz yazıdan daha güçlü ve hızlı etkiye sahip oldukları görülmektedir (Uçar, 2017: 31). Günümüzde Apple, Mc Donald's, Playstation ve Starbucks gibi global firmalar logolarında semboller kullanmaktadır.

Logolar, genellikle nesnel ölçütlere göre değerlendirilmemektedir. Bir logonun güzel veya çirkin olması, bir değer ifade etmemektedir. Logo tasarımında önemli olan logonun başarılı olmasıdır. Logonun başarılı olmasında genellikle temsil ettiği marka ile bağlantısı ve özgünlük oldukça önemlidir. Logo tasarımında, temel tasarım öğeleri ve ilkelerinin kullanımı, logonun başarılı olmasında büyük önem taşımaktadır. Logo 
tasarlarken, diğer tasarım ürünlerinden farklı olarak dikkat edilmesi gereken hususlar bulunmaktadır. Bunlardan ilki, logonun basit olmasıdır. Başarılı logolarda genellikle tek veya iki renk kullanımının yanında, basit çizgilerle tasarlandığı dikkatleri çekmektedir. Hemen her yüzeye kolaylıkla uygulanabilmesi gerektiği için basitlik, logo için oldukça önemlidir. Aynı zamanda logonun akılda kalıcı ve uygun olması da gerekmektedir. Özgün çizgilere sahip olan logolar, markaları başarıya ulaştırmaktadır.

Logo tasarımları markalar için oldukça büyük öneme sahiptir. Günümüz şartlarında rekabetin artması, ürün çeşitliliğinin çoğalması ve işletmelerin pazarlama stratejilerindeki yenilikler, marka savaşlarında her adımın doğru atılmasını gerektirmektedir. Yaşam tarzı formatının hakim olduğu günümüzde, markaların logoları, yaşam tarzlarında ön plana çıkmaktadır. Köklü işletmelerin, uygun logo kullanımlarının, marka bağımlılığı oluşturmak konusunda işletmelere ne kadar fayda sağladığı da görülmektedir.

\subsection{Temel Tasarım Ö̆̆gelerinden "Aralık" ve Logo}

Tasarımda uyulması gereken kurallar, temel tasarım öğeleri ve temel tasarım ilkeleri gibi başlıklar altında literatürde bulunmaktadır. Temel tasarım elemanları olan nokta, çizgi, form-biçim, değer, doku ve renkler, temel tasarım ilkeleri olan ritim ve hareket, aralık, koram, 1şık-gölge, zıtlık, tekrar, denge, uygunluk ve birlik kavramları dikkate alınarak kullanılırlar (Yavuz, 2019:s.80).

Temel tasarım ilkelerinden olan aralık kavramı, tasarımda kullanılan nesnelerin veya objelerin birbirlerine olan mesafeleri ile ilgilidir. Bu kavram, tasarımda anlatılmak istenilen durumu veya verilmek istenen mesajı, etkili şekilde hissettirir. Göz, objelere olan uzaklıkları, derinlik olarak "ters orantılı" olarak algılar. Uzaklık arttıkça, derinlik algısı azalır. Uzaklığı netçe algılama, derinlik ve keskinliği, ölçüsel bir değer olarak algılamadır. Gözü uyaran, en küçük iki uzaklık, görme alanındaki minör aralıktır. Görme alanında, kopukluk yaratmadan algılanabilen, en büyük uzaklık majör aralıktır. Aralık, yüzeyler, cisimler arasındaki uzaklıktır. Algılanan cismin göz seviyesinden yukarıda kalan ölçüsünün iki katı bir uzaklıktan bakışı gerektirir. Görüş uzaklığına ve görüş alanının büyüklüğüne bağlı olarak, her organizasyonun en büyük ve en küçük bir aralığı bulunur. Aralık çeşitleri ve ilkeleri aşağıdaki şekilde sıralanabilir (Atalayer, 1994, 207).

o Aynı aralık,

o Farklı aralık,

o Uygun aralık,

o Aralıksız.

Tasarımda kullanılan nesne ve objeler, simetrik şekilde aynı aralığa sahipken, asimetrik olarak farklı aralıklara da sahip olabilir. Aynı zamanda aralık türlerinden birisi olan uygun aralık modelinde ise obje veya nesneler tasarımdaki duruma göre orantılı şekilde olabilir. Aralıksız şekilde yerleştirilen obje ve nesneler de tasarımın diğer hallerinden birisidir.

Çalışmaya konu olan logoların "sosyal mesafe" temalı güncel formları, temel tasarım ögelerinden "aralık" kavramı ile örtüşmektedir. Firmaların Covid-19 sonrası güncelledikleri yeni logoları, tasarımda kullandıkları objeler arasına "aralık" uygulama esasına dayanmaktadır.

\section{YÖNTEM}

\subsection{Araştırmanın Amacı}

Çalışmanın amacı; Covid-19 salgını sonrası tüm dünyada bireylerin yaşamını etkileyen sosyal mesafe önlemleri kapsamında, markaların "farkındalık" kampanyalarının görsel tasarım unsuru olan logolar özelinde nasıl değişiklik gösterdiğinin ortaya çıkarılmasıdır. Bu kapsamda özellikle küresel çapta hizmet veren firmalara ait güncellenen logolardan örnekler incelenecektir. Markaların bir strateji olarak sosyal mesafeyi korumaya yönelik sürece destek olmak ve farkındalık yaratmak amacıyla yaptıkları bu güncellemeler, logoların Covid-19 salgını öncesi ve sonrası görselleri ile çalışmaya konu edilmiştir.

\subsection{Araştırmanın Yöntemi}

Çalışmanın uygulama bölümünde, inceleme kapsamına alınabilecek logolar internet arama motoru taraması yoluyla tespit edilmiştir. Bu kapsamda özellikle bazı haber sitelerinde konu ile ilgili içerikler tespit edilmiş, markalar logo güncellemeleri ile haberlere konu olmuştur. Sosyal mesafenin önemine dikkat çekmek için logolarını yeniden düzenleyen marka sayısının hızla arttığı, yapılan araştırma neticesinde görülmüştür. 
Ancak çalışmada kullanılacak görseller sadece küresel firmaların örnek teşkil edecek sayıdaki logo tasarımları ile sınırlandırılmıştır. Nitekim sosyal mesafe temalı logo güncelleme stratejisi, kısa sürede küresel pazardan yerele eklemlenerek, çok sayıda markanın da sürece dahil olmasını sağlamıştır.

Salgının tüm dünyada hızla yayıldığı tarih itibariyle, markaların farkındalık kampanyaları Mart-Nisan 2020'de yayınlanmaya başlamıştır. 24 Mart 2020 tarihli MediaCat internet sitesinde Audi firmasının, 25 Mart 2020 tarihinde NTV haber sitesinde Volkswagen, Audi, Hyundai, Coca-Cola, McDonalds markalarının, 2 Nisan 2020 tarihli Ekonomist internet sitesinde Audi, Mercedes, McDonalds firmalarının, 07 Nisan 2020 tarihli Yeniçağ gazetesinin haber sitesinde, Volkswagen, Audi, Coca-Cola, McDonalds firmalarının Coronavirüs sebebiyle logolarını güncelledikleri ile ilgili haberler olduğu tespit edilmiştir.

Dijital platformda yer alan haber içeriklerinde en sık görüntülenen ve en fazla habere konu olan örneklerden seçilen marka logoları tespit edilmiştir. Araştırma kapsamında ilgili kaynaklarda belirlenen, Volkswagen, Audi, Hyundai, McDonalds ve Coca-Cola firmalarının logoları, göstergebilim yöntemiyle incelenmiştir.

Nitel bir araştırma yöntemi olan "göstergebilimsel çözümleme", metinlerde yer alan göstergeler aracıllı̆ı ile görünen anlamdan ziyade işaret edilen ya da kastedilen anlamları çözümlemeye yaramaktadır Çağdaş göstergebilim ile ilgili çalışmalar incelendiğinde kaynaklarda özellikle, dilbilimci Saussure, filozof Peirce ve felsefeci Barthes'ın çalışmaları dikkati çekmektedir. Göstergebilim yöntemi ile ilgili çalışmalarda öncelikle dilsel sistemle ilgilenen ünlü dilbilimci Saussure, daha sonraki aşamada sistemin göndermede bulunduğu gerçekle nasıl ilişkilendirildiği üzerinde durmuştur. Saussure (1985:71), bir bütünü belirtmek için göstergeyi, işaret ettiği kavram yerine gösterileni ve işitim imgesi yerine de; gösteren tanımlamalarını kullanmıştır. Saussure'ün geliştirdiği yapısal yöntem dilbilimsel model çerçevesinde şekillenmiştir. Saussure göre (1998:109) anlam göstergenin içinde yer almaktadır ve gösterge "kavramla işitim imgesinin birleşimi" dir. 20. yüzyılın başlarında Saussure ile eş zamanlı göstergebilim alanında çalışan bir diğer isim; filozof Pierce'dir. Pierce, bütün olguları kapsayan, mantıkla yakından ilişkili bir gösterge kuramı üzerine çalışmalar yapmış ve bu alanı semiyotik olarak adlandırmıştır. Pierce, göstergeleri üçlükler şeklinde tanımlamıştır. En önemli üçlügü; nesne, gösterge ve yorumlayan olarak açıkladığı modeldir. Bir diğer sınıflandırması ise; gösterge, belirti ve simge üçlüğüdür (Rifat, 2009:30-34). Göstergebilimin kurucu isimlerinden olan Barthes (2016:4750)'a göre bir yöntem olarak göstergebilim; metinlerin içindeki ögelerin birbirleriyle ve bir bütün olarak dış dünya ile olan ilişkilerini çözümlemeye yaramaktadır. Toplumun olduğu her yerde tüm kullanımlar kendi göstergelerine dönüşmektedir. Toplumlar belirli standartlar çerçevesinde kalıplaşmış bir ölçü ve kurala bağlanmış nesneler üretmektedir. Bu nesneler anlam aktaran dilin sözlerini oluşturur. Gösteren bir aracıdır ve her bireyde farklı okumalar yaratabilir. Reklam metinlerinde gösteren olarak tespit edilen görsel ögeler; ürünün kendisi, logosu, nesneler, renkler, grafik ögeler gibi okuyucu tarafından görülen her şeydir (Timisi, 1997:40). Bireylerin karşısına kimi zaman görsel kimi zaman da dilsel olarak çıkan reklam iletilerini anlamlandırma süreci, reklamın hedefine ulaşmasında son derece önem taşımaktadır. Göstergebilimsel çözümlemede reklam iletisindeki üç temel öge; iletinin odaklandığı nesne, göstergeler, anlam ya da içeriktir (Küçükerdoğan, 2005:73). Ayrıca bu çözümleme yönteminde anlamlandırma sürecinde iki kavram karşımıza çımmaktadır: düz anlam ve yan anlam. Düz anlam; göstergenin nesnesel olarak sunulan ve kolayca anlaşılabilen anlamına işaret ederken, yan anlam; düz anlama bağlı ancak onun ötesinde anlamlar ima etmektedir (Dyer, 2010:182). Yan anlamın esasını oluşturan ideoloji, toplumsal olarak konumlanmış bir kodlayıcının ürünü olarak tanımlanabilir (Hall, 2006:123). Araştırmanın yönteminde Barthes'ın geliştirmiş olduğu göstergebilimsel çözümleme metodunun tercih edilmesindeki temel sebep; bu yaklaşımda daha çok popüler kültür çözümlemelerinin üzerinde çalışılmış olmasıdır. Hemen hemen bütün çalışmalarında burjuva toplumunun eleştirisini yapan Barthes, kapitalist fikirlerce desteklenen toplumsal değişim biçimlerinin yapılarını ve bahsi geçen fikirlerin kendilerini ortaya koyma biçimlerini incelemektedir (Coward ve Ellis, 2008:53). Barthes'ın, geliştirdiği yapısal çözümleme yöntemi anlam taşıyan olgulara yöneliktir. Dolayısıyla bütün bunlar anlama kavramı aracılığı ile göstergebilime bağlanır ve göstergelerle yan anlam (ikincil) gösterilenleri arasındaki bağlantılar üzerinde durur (Vardar, 2001:88).

\section{BULGULAR}

Çalışmaya konu olan reklam iletileri, tüm dünyayı etkisi altına alan Covid-19 salgın döneminde markaların farkındalık yaratmak, sosyal mesafeye dikkat çekmek, sürece destek olduklarını göstermek gibi çeşitli stratejiler amacıyla reklam araçlarında yer alan görsellerinden oluşmaktadır. Bu görseller markaların mevcut 
logolarının "sosyal mesafe" ye dikkat çekmek amacıyla tekrar güncellenmiş halidir. Görsellerin düz anlam/yan anlam bağlamında incelendiği çalışmada, küresel firmaların sosyal izolasyon ve güvenli mesafe kurallarından yola çıkarak yeniden yorumlandığı dikkati çekmektedir. Reklam iletilerinde yer alan göstergelerin yorumlanması sürecinde, düz anlam çoğunlukla evrensel bir anlamlandırma alt yapısına sahiptir. Dünya markalarının adeta küresel bir salgına dönüşen Covid-19 virüsüne karşı toplumsal boyutta sergiledikleri destek göstergeleridir. Bu durum reklam iletileri ile karşılaşan farklı toplumsal ve kültürel zeminlere sahip çok sayıda birey tarafından benzer yorumlanabilecek bir anlamlandırma düzlemine sahiptir. Ancak yan anlam yorumlanırken marka-birey etkileşimi ( örneğin reklam iletisinde yer alan marka araca sahip birey), ürün- üretim yeri bağlantısı (ürünün üretildiği ülke ve oradaki reklam kampanyaları) gibi farklı değişkenler bireylerin zihinde anlamlandırma süreçlerine etki edebilir. Böylelikle süreç sadece bir destek içerikli kampanyadan öte, takdir toplayan ya da gurur duyulan bir reklam kampanyasına dönüşebilir. Nitekim bu unsurlar marka değerini arttırmada oldukça önemlidir.

Covid-19 salgın süreci hızla devam ederken ivedilikle harekete geçen Alman markaları olan Volkswagen ve Audi sosyal mesafe temalı logoları ile dijital platformlarda kendini göstermiştir.

Bir otomobil markası olan Volkswagen'in tarihi 1930'lu yıllara dayanmaktadır. Logosu; Volks Wagen kelimelerinin baş harfleri olan VW harflerinden tasarlanmıştır. "Halk Arabası" olarak adlandırılan markanın logosunda yer alan V figürü halk (volks), hemen altında duran W figürü ise araba (Wagen) kelimelerini temsil etmektedir ${ }^{1}$. Şekil 1'de firmanın güncel olarak kullandığı logo yer almaktadır.

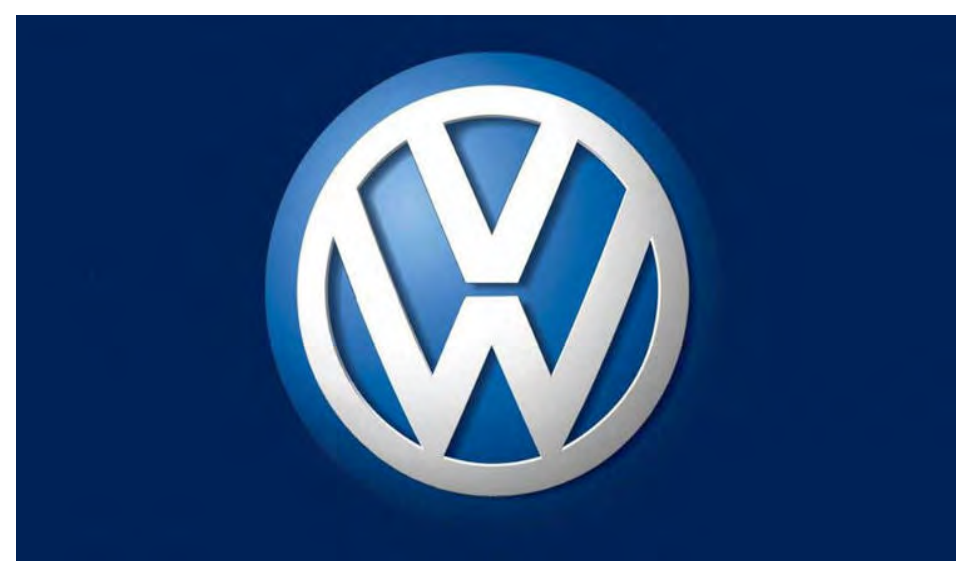

Şekil 1: Volkswagen Logosu

Kaynak: https://www.vw.com.tr (Erişim Tarihi:01.05.2020).

Şekil 2'de ise Covid-19 sonrası markanın tasarladığı yeni logosu yer almaktadır. Alman firma yeni logoda V ve W harflerini ayırarak, sosyal mesafeye dikkat çekmiş, yazılı metinde de "Sosyal mesafenizi koruduğunuz için teşekkürler" ifadesini kullanmıştır. Marka bu değişimle ilgili bir de video çekerek, logodaki değişimin halka tanıtılmasını sağlamıştır. Kampanya, markanın dijital platformlarında hızla yayınlanmış ve kısa süre içerisinde haber sitelerinde de yerini almıştır. Logo düz anlamında; sosyal mesafeye dikkat çeken bir içerik olarak yorumlanırken yan anlamında; Alman firmanın markasını süreçte konumlandırarak, akılda kalıcılığı arttırması ve konu olduğu içerikler ile hedef kitlesine sürece ilişkin hassasiyetini ifade etmesi olarak yorumlanmaktadır. Marka, güncel bir yaklaşımla sadece sürece destek vermekle kalmamış, gündemdeki yerini de korumuştur.

${ }^{1}$ Volkswagen Binek Araç, https://www.vw.com.tr (Erişim Tarihi:01.05.2020). 


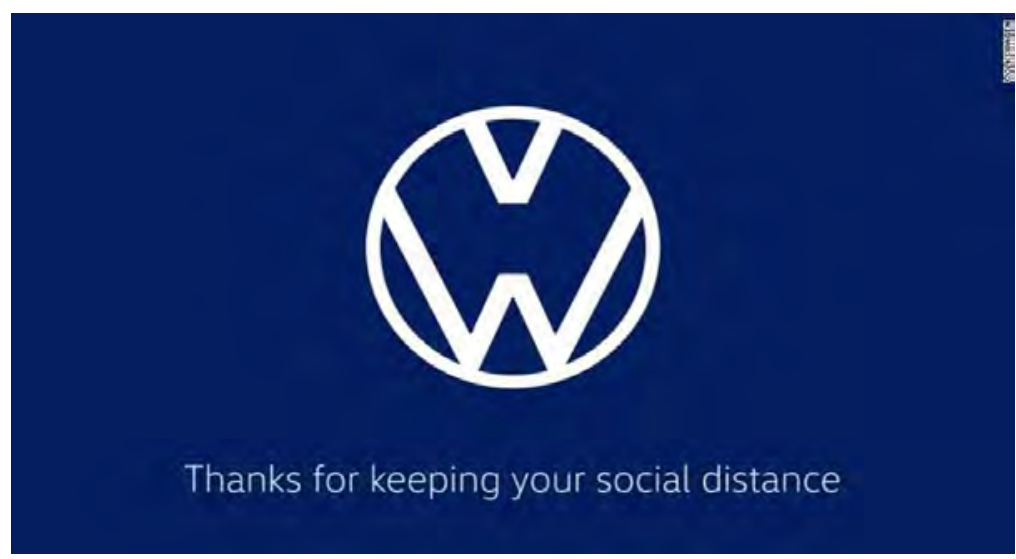

Şekil 2: Volkswagen Covid-19 Logo Güncellemesi

Kaynak: https://www.ntv.com.tr (Erişim Tarihi: 03.05.2020)

Süreçte kısa sürede aktif olmuş bir diğer Alman otomobil markası Audi'dir. Latince "dinlemek" anlamına gelen Audi, 1910 yılında kurulmuş ilerleyen yıllar içerisinde dört farklı firmanın birleşimini ifade eden iç içe geçmiş halkalardan oluşan logosu ile geçmişten günümüze kullanılmaya başlanmıştır. Şekil 3'de markanın günümüzde kullandığı logosu yer almaktadır. Dört halkanın iç içe geçmiş hali, dört farklı markanın ortak ürettikleri arabada tek amblem olarak yer almasını temsil etmektedir².

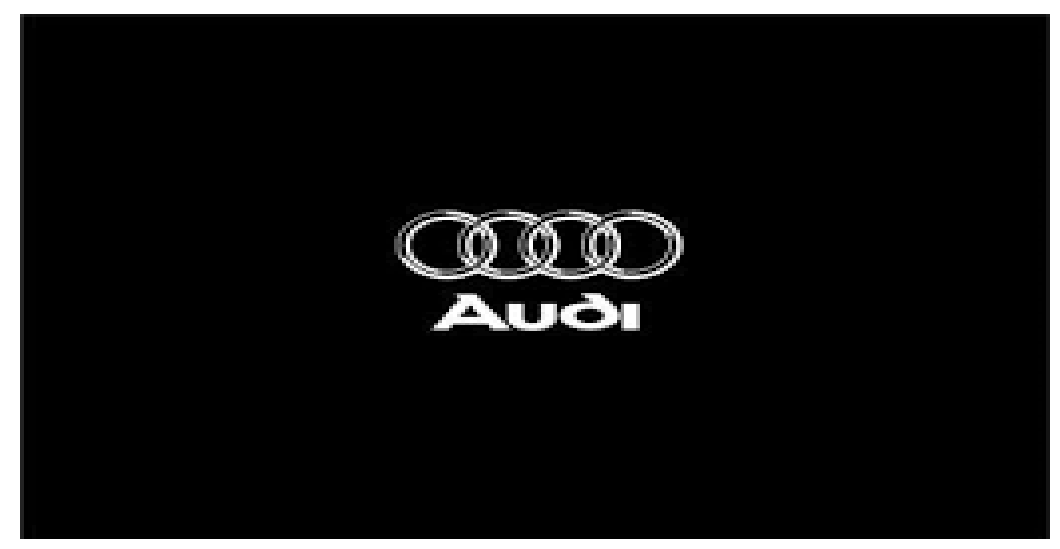

Şekil 3: Audi Logosu

Kaynak: https://www.audi.com.tr/tr/web/tr.html (Erişim Tarihi: 03.05.2020)

Şekil 4'de salgın sonrası tasarlanan yeni logo yer almaktadır. Dört halkanın birbirinden ayrı olarak konumlandırıldığı bu logo tasarımında, "Mesafeni Koru” yazılı metni yer almaktadır. Volkswagen ile benzer bir video içeriği ile yeni logosunu tanıtan Audi markası, dijital platformlarda kısa sürede içeriğin hızla paylaşılmasını sağlamıştır. Düz anlamda; birbirinden ayrı olarak yer alan halkaların sosyal mesafeye dikkat çekmek amacıyla konumlandırıldığı görülürken, yazılı metinle de bu amaç ifade bulmuştur. Yan anlamda marka; hedef kitlesine sosyal sorumluluğunun bilincinde olduğunu, sürece ilişkin uygulamaları destekleyen bir politika izlediğini ve bu kapsamda güncellemeler yaptığını ifade etmektedir.

2 Audi Şirket ve Markalar, https://www.audi.com.tr/tr/web/tr/audi-dunyasi/audi-tarihi/sirket-vemarkalar.html (Erişim Tarihi: 03.05.2020). 


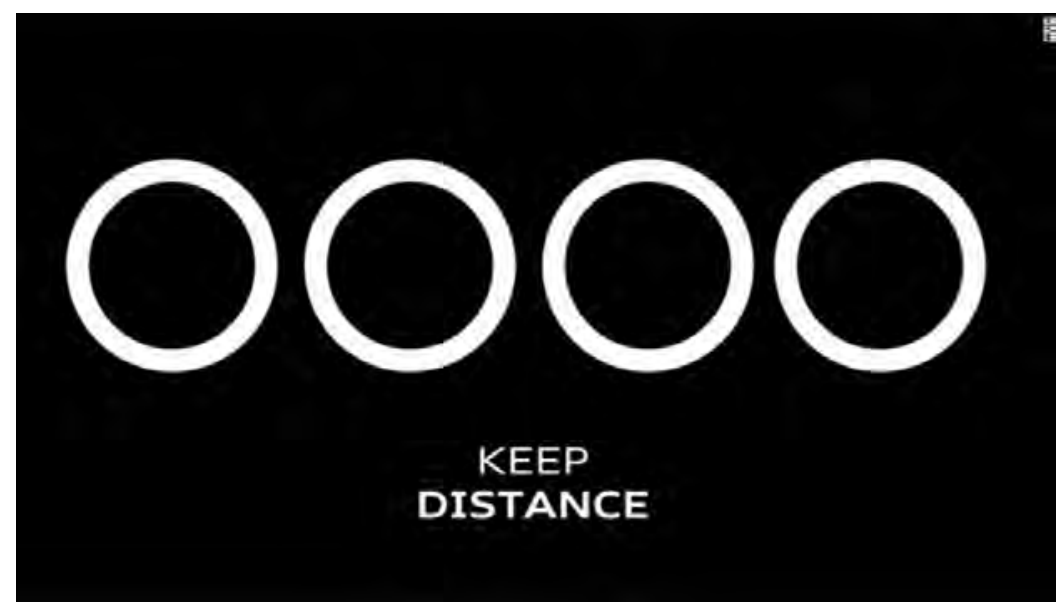

Şekil 4: Audi Covid-19 Logo Güncellemesi

Kaynak: Kaynak: https://www.ntv.com.tr (Erişim Tarihi: 03.05.2020)

Güney Kore merkezli ve çok uluslu bir firma olan Hyundai Motor Company, logosunda sosyal mesafe güncellemesi yaparak haber sitelerinde hızla yerini alan bir diğer otomobil markasıdır. Şekil 5'de görülen markanın logosundaki büyük " $\mathrm{H}$ " harfinin markanın baş harfi olmasının yanı sıra, karşı karşıya duran ve el sıkışan iki kişi olduğu, bu tasarımın müşteri ve şirket arasında bir "köprü" oluşturarak birlik ile bağlllık duygusunu simgelediği bilinmektedir³.

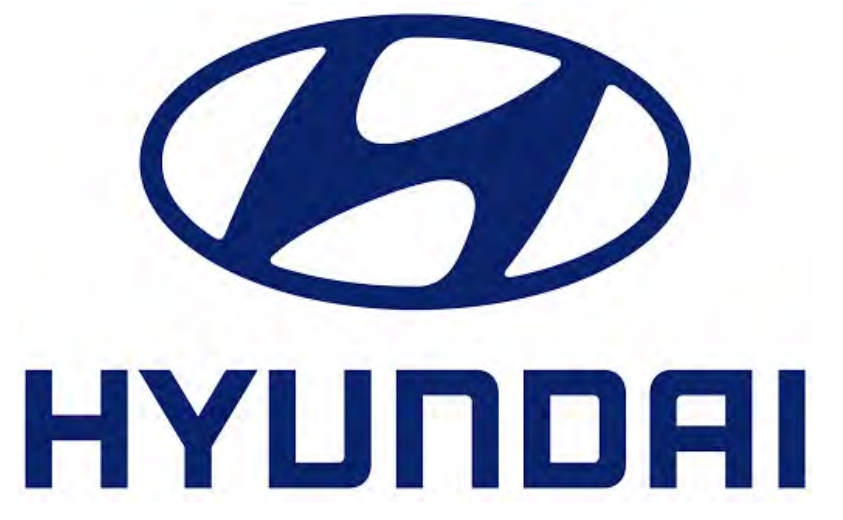

Şekil 5: Hyundai Logosu

Kaynak: https://www.hyundai.com/tr/tr (Erişim Tarihi: 03.05.2020)

Covid 19 salgını sonrası Hyundai markası da logo güncelleme planlamasıyla hızla haber sitelerinin içeriklerinde yerini almıştır. Dijital platformlarda paylaşılan yeni logo, mevcut logoda yer alan tasarımın anlamından yola çıkarak, sosyal mesafenin önemine dikkat çekecek bir tasarımla güncellenmiştir. Şekil 6'da yer alan yeni logoda, ele ele sıkışan iki kişi değil, mesafeli bir biçimde selamlaşan iki kişi görseli ile Covid-19 sonrası bireysel temasın yerini sosyal mesafeye bıraktı̆̆ına dikkat çekilmiştir. "Önce güvenlik" yazılı metni ile logo düz anlamda; birbirine temas etmeden, yine aynı sınırlarda ancak mesafeli durmanın önemine dikkat çekmektedir. Yan anlamda ise; Hyundai firmasının salgın döneminde sosyal mesafe temalı uygulamaları desteklediğini, bu kapsamda faaliyetlerini güncellediğini, el sıkışmanın yerine mesafeli selamlaşma ile aynı ortamda olmanın önemini belirtmektedir. Marka, dijital platformlar aracılığıyla yeni logosunun tasarımını paylaşmış ve çok sayıda haber içeriğinde de yer almıştır.

\footnotetext{
${ }^{3}$ Hyundai Logo Tasarımı, https://www.dijitalajanslar.com/hyundai-logosundaki-gizli-anlam/ (Erişim Tarihi: 02.05.2020)
} 


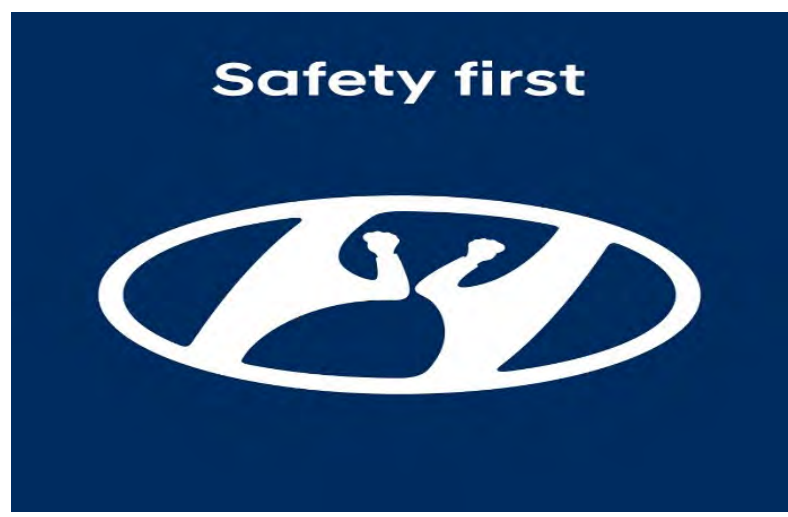

Şekil 6: Hyundai Covid-19 Logo Güncellemesi

Kaynak: https://www.ntv.com.tr (Erişim Tarihi: 03.05.2020)

Küresel çapta fast-food endüstrisinin önemli lokomotiflerinden olan Amerikan McDonalds firması da, Covid19 sonrası logo güncellemesine giden markalar arasındadır. Ünlü " $\mathrm{M}$ " logosu, kurucusunun soyadından esinlenerek tasarlanmış olan marka, günümüzde dünya çapında 34 bini aşkın restoran, 1,6 milyonu geçen çalışan ile günde ortalama 58 milyon müşteriye hizmet vermektedir. 2017 Brand Z Raporu'na göre dünyanın en değerli sekizinci markasıdır. ${ }^{4}$ Marka hızla yayılan salgın sonrası alınan tedbirler kapsamında hizmet imkanlarını sınırlandırmış ve sosyal mesafenin önemine dikkat çeken yeni logo tasarımı ile dijital platformlarda kendini göstermeye başlamıştır. Aşırı tüketim, hızlı ve sağlıksız beslenme gibi gerekçeler ile sıklıkla gündeme gelen marka, Şekil 7'de yer alan klasik logosundaki çift renkli tasarımı ile tanınırlı̆̆ı son derece yüksek bir görsele sahiptir.

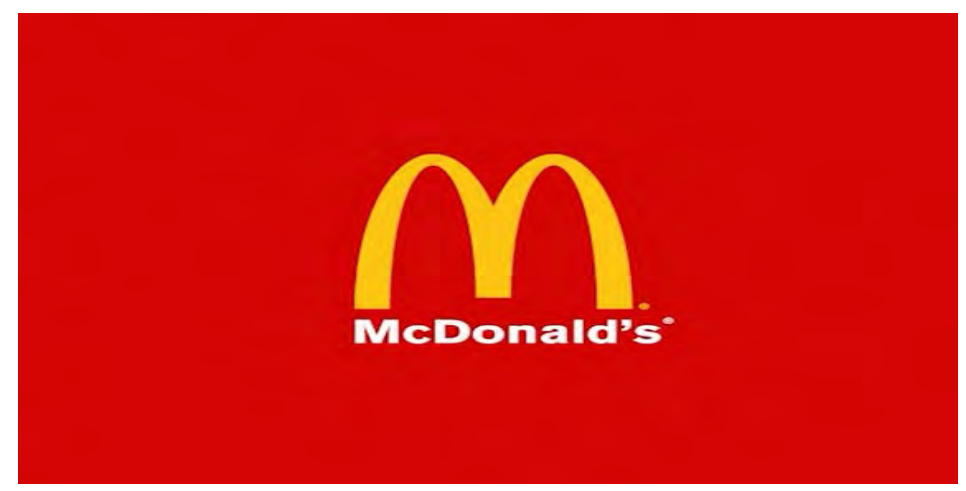

Şekil 7: McDonals's Logosu

Kaynak: https://www.mcdonalds.com.tr (Erişim Tarihi: 02.05.2020)

Covid-19 salgını sonrası ikonik "M" harfini ayıran logo düz anlamda; sosyal mesafeye dikkat çekecek bir tasarımla yeni logo akımına hızlı bir şekilde katılmıştır. Şekil 8'de yer alan markanın yeni logosu ilk olarak McDonald's Brezilya'nın Facebook sayfasında yayınlanmıştır ${ }^{5}$. "her zaman birlikte olabiliriz" açıklaması ile paylaşılan yeni logo yan anlamda; markanın sosyal mesafe kuralları kapsamında eve teslim ve arabaya hizmet gibi uygulamaları ile müşteri ile birliktelik sürecini ve marka değerini arttırma stratejisini devam ettirdiğini ifade etmektedir.

\footnotetext{
${ }^{4}$ McDonald's Hakkında, https://www.mcdonalds.com.tr/hakkimizda (Erişim Tarihi: 02.05.2020).

${ }^{5}$ McDonald's Brazil, https://edition.cnn.com/2020/03/26/business/social-distancing-brand-logoscoronavirus/index.html (Erişim Tarihi: 02.05.2020).
} 


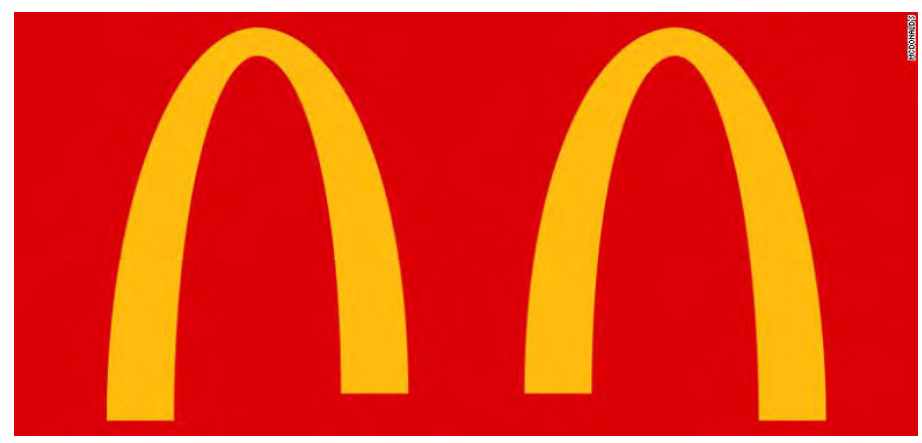

Şekil 8: McDonalds Covid-19 Logo Güncellemesi

Kaynak: https://www.ekonomist.com.tr/ (Erişim Tarihi: 03.05.2020)

Dünyanın en popüler alkolsüz içeceklerinden biri olan Coca Cola markası da logo güncellemesi ile sürece dahil olan firmalar arasındadır. Spencerian fontuyla yazılan logo, ürün ambalajı yıllar içinde değişse de standart olarak kalan önemli bir marka temsilidir. Şekil 9'da yer alan logo ana hatları ile markanın yıllardır değişmeyen logosudur.

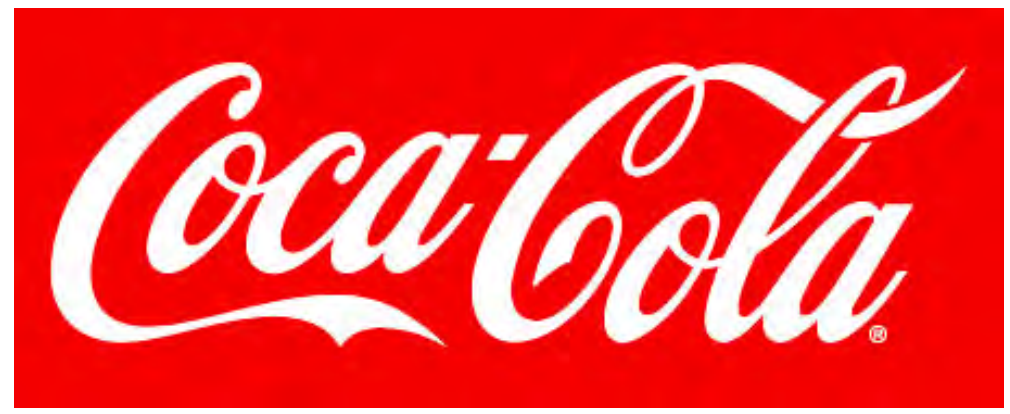

Şekil 9: Coca-Cola Logosu

Kaynak: http://www.coca-cola.com.tr/tr/home/ (Erişim Tarihi: 02.05.2020)

Covid-19 salgını sonrası tasarlanan yeni logo ilk olarak Amerika'da Times Square meydanındaki dev panoda gösterilmiş daha sonra dijital platformlarda yayınlanmıştır. Spencerian Script fontuyla yazılan Şekil 10'daki logoda harflerin arasına boşluk bırakılarak sosyal mesafenin önemine dikkat çeken yeni tasarımı, düz anlamda "Ayrı kalmak birleşmenin en iyi yoludur." yazılı metni ile markanın sürece ilişkin uygulamalara verdiği desteği ifade etmektedir. Küresel pazar payı son derece yüksek bir marka olan Coca Cola, özellikle dünya genelinde uygulanan karantina döneminde yeni logo tasarımı ve "sosyal mesafeyi uygula", "güvende kal" sloganları ile sürece desteğini tüm dijital platformlardan duyurmuştur. Yan anlamda marka, çağrışımı çok güçlü olan logosunu salgın döneminde güncelleyerek, bir kamu spotu mahiyetinde tasarlanmış yeni logosu ile tüketicinin zihninde olumlu izlenim yaratarak ürüne yönelik marka değerini arttırmayı amaçlamıştır.

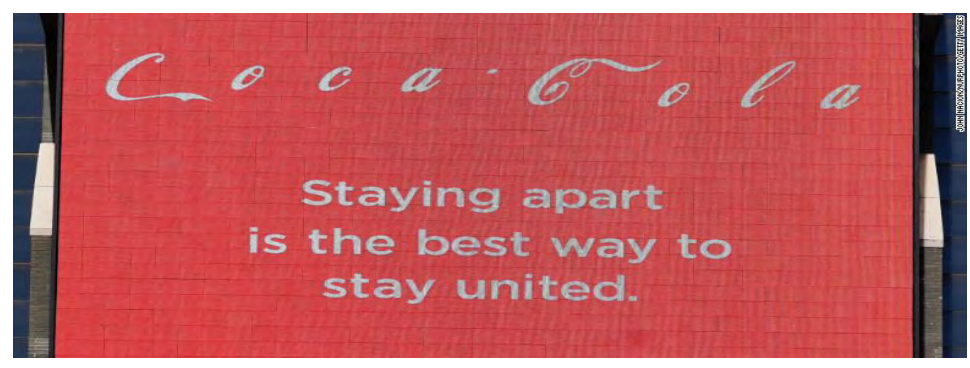

Şekil 10: Coca Cola Covid-19 Logo Güncellemesi

Kaynak: https://www.ekonomist.com.tr/ (Erişim Tarihi: 03.05.2020)

\section{SONUÇ VE TARTIŞMA}

Medya araçları, ideolojik temsiller ve egemen ideoloji söylemlerinin üretildiği ve yaygınlaştırıldığı araçlardır. $\mathrm{Bu}$ araçlar, ana akım medyada yer almaktadır ve ana akım medya homojen izler kitleye yayın yapan ve hakim 
söylemlerin taşıyıcısı bir yapıdadır (Bailey, vd., 2007:18). Medyada yer alan reklam iletileri toplumlarda yaşanan sosyo-ekonomik süreçlerle de yakından ilişkilidir. Hedef kitlenin ilgisini, dikkatini ve beğenisini çekmek, tüketime teşvik etmek, marka bilinirliğini artırmak, farkındalık yaratmak gibi çok sayıda farklı nedenle reklam iletileri yayınlanmaktadır.

Covid-19 salgını sonrası dünya genelinde sosyo-ekonomik dengelerin değiştiği, ülkelerin hem kendi içlerinde hem de uluslararası düzeyde izolasyon sürecini başlattıkları bir dönem yaşanmaktadır. Salgının insan sağlığını tehdit eden ve ciddi sonuçlar doğuran yayılımı nedeniyle onlarca ülke çeşitli önlemler alarak süreci yönetmeye çalışmaktadır. Bu önlemlerin başında da bireylerin kişisel temastan uzaklaşarak araya mesafe koymalarını gerekli kılan "sosyal mesafe" uygulamaları gelmektedir. Salgının yayılımındaki en önemli unsurlardan biri olan temasın, mümkün olduğunca aza indirilmesi amaciyla ilk etapta uygulamaya koyulan "sosyal mesafe" önlemleri markaların da gündeminde yerini almıştır. Literatürde yer alan "sosyal mesafe" özelindeki çalışmaların, salgın sonrası kullanılan "sosyal mesafe" tanımlamaları anlamı ile tutarlılık göstermediği çalışma kapsamında tespit edilmiştir. Nitekim "sosyal mesafe" günümüz şartlarında bir tercih değil, gerekliliktir. Kavramın son dönemde kullanılan ve giderek yaygınlaşan anlamına dikkat çekmesi açısından çalışmanın literatüre katkı sağlayacağı düşünülmektedir.

Kamu sağlığını korumak, sürece destek vermek, marka bilinirliğini ve değerini arttırmak gibi çok sayıda gerekçe ile markalar da "sosyal mesafe" özelinde kampanyalar hazırlamıştır. Çalışmaya konu olan markaların güncellenmiş logoları bu kampanyalardan birisidir. Marka kimliklerinin önemli bir unsuru olan logoların, "sosyal mesafe" temalı güncellenme süreci önemli bir marka iletişimi çalışmasıdır. Markaların bu süreçte kendilerini görünür kılarak logo güncellemeleri ile vermek istedikleri mesajlar şöyle sıralanabilir:

- Sosyal mesafe uygulamalarına dikkat çekmek

- Bir marka stratejisi olarak markanın görünürlügüüü arttırmak

- Sürece destek olarak tüketicinin zihninde olumlu izlenim yaratmak

- Marka değerini arttırmak

- Süreci bir reklam stratejisi olarak yönetmek ve içeriklere konu olmak

- Haber içerikleri ile marka bilinirliğini arttırmak

Çalışma kapsamında Covid-19 sonrası logo güncellemesi uygulamasının dünya çapında küresel firmalar tarafından başlatıldığı ve sonrasında küreselden yerele bir uygulamaya dönüştüğü gözlemlenmiştir. "Sosyal mesafe" kavramına tercih değil gereklilik olarak yeni bir anlam kazandıran süreç, logoların güncellenerek görsel açıdan da bir değişim yaşanmasına neden olmuştur. Bu değişim sosyal sorumluluk, destek ve dikkat çekmek gibi anlamlar içerse de esasen markaların çeşitli stratejilerine de hizmet etmektedir. Kısa vadeli olduğu düşünülen logo güncellemelerinin ne kadar daha süreçte kullanılacağı belirsizliğini korumaktadır. Markaların bu süreçten ekonomik olarak nasıl bir tablo ile çıkacakları ve yeni reklam stratejilerini nasıl planlayacakları farklı araştırmalara kaynaklık edebilecek konular arasındadır. 


\section{KAYNAKÇA}

Ak, M. (1998). Firma/ Markalarda Kurumsal Kimlik ve İmaj. Işıl Ofset, İstanbul

Akalan, G., Göktaş, B., Erdoğan Tarakçı, İ. (2019). Markalaşma Çalışmaları: Türkiye'de Kahve Zinciri Olan Bir Kobi'nin İncelenmesi, İşletme Araştırmaları Dergisi, 11 (2), 787-805.

Atalayer, Faruk. (1994). Temel Sanat Öğeleri. Anadolu Üniversitesi Yayınevi, Eskişehir

Bayraktaroğlu, A. M., Çalış, E. (2010). Amblem ve Logo Tasarımlarında Yalınlaştırmalar. Art-e Sanat Dergisi, 3 (6), 1-22.

Bailey, O.. Cammaerts, B. ve Carpentier, N. (2007). Understanding Alternative Media. Open University Press, Berkshire

Barthes, R. (2016). Göstergebilimsel Serüven. Çev: M. Rifat. Yapı Kredi Yayınları, İstanbul

Becer, E., (1997). İletişim ve Grafik Tasarım, 1. Baskı, Dost Kitabevi Yay., Ankara.

Bilgiç, M. S., Koydemir, F. S. ve Akyürek S. (2014). Türkiye'de Kimlikler Arası Kutuplaşmanın Sosyal Mesafe Üzerinden Ölçümü ve Toplumsal Güvenliğe Etkisi. Bilge Strateji, Cilt 6, Sayı 11, ss.163-205

Bogardus, E. S. (1925). Measuring social distance. Journal of Applied Sociology, 9, 299-308.

Bogadrus, E. S., ( 1959), Social Distance, Yellow Springs, Antioch Press, Ohio

Bozkurt, F. (2015). Logolardaki Değişikliklerin İncelenmesi (Vaka Analizi), Yüksek Lisans Tezi, Bahçeşehir Üniversitesi, İstanbul, ss.49-51.

Budak, S., (2000), Psikoloji Sözlüğü, Bilim Sanat Yayınları, Ankara

Chen, H.; Xu, W.; Paris, C., Reeson, A.; Li, X. (2020). Social distance and SARS memory: impact on the public awareness of 2019 novel coronavirus (COVID-19) outbreak. Medrxiv The Preprint Server For Health Sciences. https://www.medrxiv.org/content/10.1101/2020.03.11.20033688v1 Erişim Tarihi: 15.04.2020

Coward R, ve Ellis J. (2008) Dil ve Maddecilik, (çev. Veysel Kılıç) İstanbul: Toroslu Kitaplı̆̆ı

Dyer, G. 2010. Iletişim Olarak Reklamcilık. Çev. N. Taşkıran. Beta, İstanbul

Eser, H. B. ve Uygur, M. R. (2019). Suriyeli Göçmenlere Yönelik Tutumların Bütünleşik Tehdit ve Sosyal Mesafe Kuramları Doğrultusunda İncelenmesi: Süleyman Demirel Üniversitesi Örneği. Liberal Düşünce Dergisi, Y11:24, Say1:95, ss.131-162.

Hall, S. 2006. Encoding/decoding. D. Kellner ve G. Durham (Der.), Media and cultural studies: Keyworks içinde (s. 163 - 174). Blackwell, London

Karakayalı, N. (2015). The Wiley Blackwell Encyclopedia of Race, Ethnicity, and Nationalism, Online Library, Wiley

Karslı, B. (2013). Toplumsal Birlikteliklerde Oncelikler: Kabullenme ve Dışlamanın Sosyo-Psikolojik Temelleri (Alevilik-Sünnilik Örneği), Birey ve Toplum, Cilt:3, Sayı:6.

Küçükerdoğan, R. 2005. Reklam Söylemi. Es Yayınları, i̇stanbul

Marshall, G., (1999), Sosyoloji Sözlüğü, (Çev. Osman Akınhay-Derya Kömür- cü), Bilim ve Sanat Yayınları, Ankara

Magee, J. C. ve Smith, P. K. (2013). The social distance theory of power. Personality and Social Psychology Review, 17(2), 158-186.

Parlak, H. (2011). Temel Grafik Tasarım Bilgisi, Ege Üniversitesi Basımevi, İzmir , ss.128-129.

Ries, A. Ve Ries, L., (2004). Marka Yaratmanın 22 Kuralı, çev. Atakan Özdemir, 3.Baskı, Mediacat Yay., İstanbul.

Rifat, M. (2009). Göstergebilim ABC'si, İstanbul: Say.

Saussure, F. (1998). Genel Dilbilim Dersleri. (çev. B. Vardar). İstanbul: Multilingual

Tarakçı, E., İ. (2019). Perakendecilikte rekabet silahı olarak perakendeci markası ve Ankara ilinde bir 
M. Gençyürek Erdoğan - V. Yavuz 12/3 (2020) 2501-2514

uygulama. Hitit Üniversitesi Sosyal Bilimler Enstitüsü Dergisi, 12(2), 574-592. doi: 10.17218/hititsosbil.636143

Timisi, N. (1997). Medyada Cinsiyetçilik. T.C. Başbakanlık Kadın Statüsü ve Sorunları Genel Müdürlüğü Yayınları, Ankara

Uçar, T., F. (2017) Görsel İletişim ve Grafik Tasarım, İnkılap Kitabevi, İstanbul, ss.45.

Üstel, F. ve Caymaz, B. (2009). Seçkinler ve Sosyal Mesafe. İstanbul Bilgi Üniversitesi Sivil Toplum Çalışmaları Merkezi, İstanbul

Yiğitoğlu, G. T. ve Vural, K. B. (2019). Toplumun Sığınmacı Bireylerle ilgili Sosyal Mesafe ve Kayg1 Durumlarının Belirlenmesi. Uluslararası Toplum Araştırmaları Dergisi, Cilt:11, Sayı: 18.

Yavuz, V. (2019) İnternet Haber Sitelerinin Tasarımında Sanat Yönetimi, Doktora Tezi, Yıldız Teknik Üniversitesi Sosyal Bilimler Enstitüsü, İstanbul.

Vardar, B. (2001). Dilbilimin Temel Kavram ve İlkeleri. İstanbul: Multilingual Yayınları

Wilder-Smith, A. ve Freedman, D.O. (2020) Isolation, quarantine, social distancing and community containment: pivotal role for old-style public health measures in the novel coronavirus (2019-nCoV) outbreak, Journal of Travel Medicine, p.1-4.

World Health Organizarion, (2020). Coronavirus disease 2019 (COVID-2019) Situation Report, https://apps.who.int/iris/bitstream/handle/10665/331685/nCoVsitrep01Apr2020-eng.pdf, Erişim Tarihi: 16.04.2020. 